\title{
THE CYPRESS HILLS: VISITORS AND LAND USE
}

by Robert C. Scace, Department of Geography, The University of Calgary

The American geographer, Gilbert F. White, has said, "At the heart of managing a natural resource is the manager's perception of the resource and of the choices open to him in dealing with it. At the heart of decisions on environmental quality are a manager's views of what he and others value in the environment and can preserve or cultivate." (White, 1966, p. 105). Decisions made with respect io public reserves in Canada are of particular interest for from them are derived a muliplicity of products, the acquisition of which at source may precipitate not only competition and conflict between specific resource users but may also deny the principle of public welfare, which is supposed to be the central tenet in the administration of these areas.

The provincial parks and forest reserves of Alberta and Saskatchewan are areas that are highly desirable for a variety of outdoor recreational experiences and increases in annual visitor totals attest to their growing popularity. However, many of these lands were first established as Dominion Forest Reserves about the turn of the century and land use management has traditionally favoured those individuals or groups who have until recently made the greatest use of the public land resources - productionoriented graziers, loggers, miners and so on. Policies for public reserves (other than national parks) which did not originate as federal forest reserves have tended to follow similar lines.

In contrast, the growing number of recreationists from urban environments who use these areas are primarily consumers. Spokesmen for this group oppose existing land use practices on many public reserves "asserting that the actions they seek to prevent are destructive of values which should be acknowledged." (Held, 1967, p. 154). They contend that prevailing multiple-use policies are largely indifferent towards changing social condi- tions, and that greater emphasis must be placed upon aesthetic values for which there is a real but less easily measured economic justification. This position is supported by professional workers in a great variety of disciplines, as well as by many civil servants.

Resource managers are thus faced with the difficult task of modifying existing policies for public reserves. The historic multiple-use approach to land management is inconsistent with the demands upon these areas for a variety of recreational experiences and the corresponding (and growing) outlay of public capital to provide facilities for visitors. However, one aspect of the resource management problem is of particular interest here. It is the attitude of a particular resource user, the recreationist, towards the maintenance of different types of land use in public reserves. Because of my interest in the perceptions, attitudes and knowledge of the vacationing public I conducted a survey amongst visitors to the Cypress Hills Parks of Alberta and Saskatchewan.

The Cypress Hills have long been recognized by those who have visited them as "unique," "an anomaly," "an oasis in the desert," "the hills that shouldn't be," and other fittingly descriptive phrases which excite the imagination. Precisely why the Cypress Hills exist and support the flora and fauna that they do may only be vaguely understood by most people who visit them. But that visitors generally are aware that the Cypress Hills should be managed so as to protect those landscape features which do make them so ecologically important does seem an acceptable premise. Unfortunately, over time, and through the administrations of first, the Dominion government and subsequently, the respective provincial administrations, the landscape of the Cypress Hills reserves has been considerably modified. For example, despite several recom- 
mendations made between 1954 and 1967 that efforts be made to reduce overgrazing in the West Block in Saskatchewan, the authors of the Master Plan for Cypress Hills Provincial Park (1969, p. 51) were forced to conclude that "it would appear that there is little or no improvement in the West Block despite efforts to more effectively distribute the grazing pressures." (Italics are those of the report).

What land uses, then does the visitor approve or disapprove of in these reserves? A questionnaire was prepared which listed 37 different types of land use activity which are or have been practised in the Cypress Hills reserves. Visitors were asked whether they believed that these activities should be permitted in the two provincial parks and the West Block. If they approved of a particular type of land use but had reservations as to how, where and when it should be permitted, their approval had to be a "qualified yes." The results of the questionnaire are shown on the accompanying table.

In August, 1969, during Labour Day weekend, the questionnaires were disributed at Elkwater townsite and the main service area in the Saskatchewan ark amongst an unstructured sample of 172 people, predominantly among railer and camper groups occupying campgrounds. (As the fire hazard was extremely high, all visitors had been confined to these locations). One hundred and fifty returns came from Alerta, reflecting a larger population irom which to draw the sample, as well is limitations upon time. Slightly less han two-thirds of the respondents ived in Alberta, notably in Medicine lat (about 60), and Calgary (about 7). About one-fifth came from Sasatchewan and a similar number from he United States, principally from Montana.

It is obvious from the results of the uestionnaire that non-recreational and uses found little favour with the isiting public, even though some night be related to the quality of a recreational experience. For instance, some of the best fishing is enjoyed in reservoirs impounded by dams for

Table. Per cent Approval/Disapproval of land uses in the Cypress Hills.

\begin{tabular}{|c|c|c|c|}
\hline Land Use & $\begin{array}{l}\text { lete } \\
\text { val }\end{array}$ & $\begin{array}{l}\text { Qualified } \\
\text { Approval }\end{array}$ & $\begin{array}{l}\text { Disap- } \\
\text { proval }\end{array}$ \\
\hline Hiking & 97 & 3 & 0 \\
\hline Row, sail boats & 97 & 3 & 0 \\
\hline Swimming . & 96 & 4 & 4 \\
\hline Tent camping & 96 & 3 & \\
\hline Campers/trailers & 95 & 4 & 1 \\
\hline Sport fishing ........ & 95 & 3 & \\
\hline Driving, pleasure & 90 & 8 & \\
\hline Horse riding ......... & 89 & 7 & 4 \\
\hline Dancing ......... & 86 & 10 & 4 \\
\hline Downhill skiing ... & 86 & 8 & 6 \\
\hline Cross country skiing & 86 & 8 & 6 \\
\hline Winter carnivals .... & 82 & 11 & 7 \\
\hline Blacktopping roads.. & 85 & 7 & 8 \\
\hline Golf & 82 & 8 & 10 \\
\hline Water skiing . & 78 & 11 & 11 \\
\hline Tree planting & 75 & 12 & 11 \\
\hline Power boating & 71 & 15 & 14 \\
\hline Scientific research.... & 61 & 19 & 20 \\
\hline Rock collecting ........ & 68 & 11 & 21 \\
\hline Skidooing .......... & 62 & 17 & 21 \\
\hline Motels ..... & 58 & 20 & 22 \\
\hline Inst. camps & 66 & 11 & 23 \\
\hline Summer cottages .... & 64 & 12 & 24 \\
\hline Pesticide spraying .. & 50 & 20 & 30 \\
\hline Artifact coll. ............ & 53 & 15 & 32 \\
\hline Trail bikes ................ & 53 & 11 & 36 \\
\hline Aeroplanes/copters.. & 34 & 18 & 48 \\
\hline Hay cutting .............. & 29 & 20 & 51 \\
\hline Dams for irrigation & 32 & 15 & 53 \\
\hline Cattle grazing ........ & 15 & 16 & 69 \\
\hline Car rallying .... & 25 & 5 & 70 \\
\hline Picking flowers ...... & 21 & 8 & 71 \\
\hline Sport hunting ....... & 15 & 10 & 75 \\
\hline Prospecting ..... & 8 & 7 & 85 \\
\hline Timber cutting & 4 & 10 & 86 \\
\hline Gravel extraation .... & 6 & 4 & 90 \\
\hline Mining $\ldots \ldots \ldots \ldots \ldots \ldots$ & 2 & 3 & 95 \\
\hline
\end{tabular}


irrigation purposes, yet for which only $47 \%$ approval was recorded. The disfavour with which the sample held any form of timber cutting, prospecting for minerals, gravel extraction and mining was impressively high. Yet, although the public may emphatically reject such land uses as being in some way incompatible with the purposes of a protected public park (and this may well explain the poor support for sport hunting), agencies administering these reserves are likely to pay scant attention to these sentiments. For example, in Alberta this year, the provincial government has given permission for gas well development in the Cypress Hills Park even though widespread public concern caused the cabinet to at least temporarly suspend its agreement with the company coneerned. (Calgary Herald, May 13, 14, 15, 27, 1970).

The following remarks seem relevant to the data collected. The Cypress Hills are very attractive to the visiting public for a variety of recreational activities, but relatively few persons have any great concern about the number and character of recreational land uses which should be permitted.

Many respondents suggested that the Cypress Hills were very beautiful and should be "kept natural." The thought that mining and other nonrecreational land uses might reduce this "naturalness" seems to have encouraged many to have disapproved of these land uses. Few, however, seemed aware that growing numbers of recreationists in the Hills, the activities they participate in, and the recreational facilities which they desire and are gradually being provided with, can also do much to modify the landscape of the parks. Thus, while this survey indicates what the visiting public approves of and presumably finds desirable in the way of land use, it also points to that same public as being unsophisticated in its appreciation of the possible consequences upon the landscape of getting what it wants.

A great responsibility devolves, therefore, upon the agencies respons- ible for the administration, management and planning of the Cypress Hills reserves. The recreational aspirations of the visiting public must be evaluated and then accommodated without seriously diminishing the quality of the resource and, in turn, the quality of the recreational experience. Managers must choose between perceived alternatives in the selection of recreational facilities, bearing in mind that the Cypress Hills environment is indeed a unique one, physically, ecologically and culturally. They must recognize that unless carefully planned, recreational developments will modify the environment of the Cypress Hills just as significantly as do the productionoriented activities.

There is, in turn, a responsibility on the part of researchers, individual citizens and organizations such as the Saskatchewan Natural History Society to ensure that proposed recreational developments in protected areas such as the Cypress Hills receive full public approbation before they are acted upon by the administrating agencies. It is suggested that the governments of the provinces of Alberta and Saskatchewan place their proposals for future development of the Cypress Hills parks before citizens of the province at public hearings. This procedure would complement a similar process now underway in all of our national parks and in Alberta for the Wilderness Areas Act, and would assure the public that its interests were being recognized in the planning process.

\section{LITERATURE CITED}

Alberta Chamber of Commerce. 1970. Albert: Chamber of Commerce policy statements an resolutions, 1969-1970.

Government of Alberta. Dept. of Lands an Forest. Provincial parks policy. Edmonton

Government of Saskatchewan. Dept. of Natura Resources. 1969. Master plan for Cypres Hills Provincial Park. Regina.

Held, R. B. 1967. Whose public lands? Ir Natural Resources Journal, 7 (2) :153-161.

White, G. F. 1966. Formation and role o public attitudes. In Environmental quality ir a growing economy, H. Jarrett, ed. Balti more, The Johns Hopkins Press, for Re. sources for the Future, Inc., pp. 105-127. 